\title{
1. A különleges jogrend elméleti kérdései
}

\section{TRÓCSÁNYI LÁSZLÓ}

A koronavírus okozta járvány kitörése és gyors elterjedése szükségessé tette a világ sok táján jó ideje leginkább csak az egyetemi előadások elméleti és a hétköznapi élet valóságától távoli kérdéseként ismert kivételes hatalomgyakorlás és különleges jogrend intézményének gyakorlatban történő alkalmazását. Számos ország vezetője a járványt leginkább háborúval, annak közegészségügyi következményeit pedig egy háború által okozott csapással tartotta öszszevethetônek. Bár nemzetközi jogi értelemben a hasonlat nyilvánvalóan sántít, ugyanakkor mégis jól rávilágít a járvánnyal szembeni védekezés azon sajátosságára, hogy a veszély sikeres elhárítására és orvoslására az államszervezeti struktúra és az állami múködés hagyományos rendje nem alkalmas. A járványügyi védekezés, különösen pedig az egészségügyi ellátórendszerek túlterheltségének megfékezése, de közben a gazdaság müködőképességének lehetőség

I A járvány által előidézett veszélyt hadiállapothoz hasonlította többek között a kínai elnök és kommunista pártfötitkár Xi Jinping (www.xinhuanet.com/english/2020-02/11/c_138771934.htm, letöltve: 2020. december 15.), Emmanuel Macron francia elnök (www.reuters.com/article/us-health-coronavirus-macron-restriction/ we-are-at-war-france-imposes-lockdown-to-combat-virus-idUSKBN2133G5, letöltve: 2020. december 15.), valamint az amerikai elnök, Donald Trump is (www.whitehouse.gov/briefings-statements/remarks-presidenttrump-vice-president-pence-members-coronavirus-task-force-press-briefing-5/, letöltve: 2020. december 15.). Ilyen nyilatkozatot tett a magyar miniszterelnök, Orbán Viktor is 2020 őszén (http://abouthungary.hu/ blog/pm-orban-in-an-exclusive-interview-our-war-plan-against-the-coronavirus-is-about-ensuring-thathungary-continues-to-function/, letöltve: 2020. december 15.).

Prof. Dr. Trócsányi László, CSc

laszlo.trocsanyi@mfi.gov.hu

egyetemi tanár (Károli Gáspár Református Egyetem Állam- és Jogtudományi Kar, Alkotmányjogi Tanszék; Szege-

di Tudományegyetem Állam- és Jogtudományi Kar, Nemzetközi és Regionális Tanulmányok Intézete)

tiszteletbeli elnök (Mádl Ferenc Összehasonlító Jogi Intézet)

Trócsányi, L. (2021) 'A különleges jogrend elméleti kérdései’ in Nagy, Z., Horváth, A. (szerk.) A különleges jogrend és nemzeti szabályozási modelljei, 26-36. o. Budapest: Mádl Ferenc Összehasonlító Jogi Intézet.

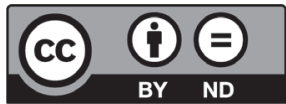

https://doi.org/10.47079/2021.nzha.kulon.4_1 
szerint való megőrzése ${ }^{2}$ a hagyományos, békeidőszaktól eltérő államhatalmi szervezeti rend és múködés bevezetését indokolta. ${ }^{3} \mathrm{~A}$ különleges jogrend jó pár évtizede elméleti jogászkodásra ítélt kérdései így váltak az európai és Európán kívüli országok mindennapjainak részévé 2020ban, a kitört Covid-19-járvány időszakában. A jelen kötet ezen apropóból tekinti át a közjó érdekében alkalmazott, normálistól eltérő, kivételes állami müködést.

A különleges jogrend átfogó jellegú tárgyalására vállalkozó összehasonlító jogi kötet megkerülhetetlen része azonban a magát a különleges jogrendet övezőáltalános elméleti kérdések megismerése és bemutatása. A különleges jogrend alkotmányos rendszerben betöltött helyének bemutatására és tárgyalására már csak azért is nagy szükség mutatkozik, mert a rendszerváltoztatást megelőző hazai történelemben számos rossz emlék is tapad - az alkotmányos hagyományoktól elszakadt - kivételes hatalomgyakorlás intézményéhez. Ezért az egyes európai és Európán kívüli országok rendkívüli állapotot és különleges jogrendet szabályozó tételes jogi szabályozásainak vizsgálatát megelőzően érdemes a különleges jogrend legalapvetőbb elméleti kérdéseit bevezető jelleggel felvázolni. Melyek a kivételes hatalomgyakorlás történelmi gyökerei, és miért válhat ilyen hatalomgyakorlás szükségessé az alkotmányos rendszerekben? Mikor jelent meg az alkotmányjogi szabályozásuk, és mikor váltak az alkotmányjog részévé? Mi igazolhatja bevezetését, és melyek az alkalmazásának alapvető feltételei? Mi a funkciója, és milyen érdekeket vagy értékeket véd? Ezek azok az alapvető kérdések, amelyeket a tanulmány törekszik megvizsgálni. A különleges jogrend eredetének, államelméleti hátterének és igazolhatóságának feltárása és tárgyalása ahhoz kíván hozzájárulni, hogy a kötet összehasonlító jogi részei érthetőbbé válhassanak. Ennek érdekében jelen tanulmány elsőként górcső alá veszi a különleges jogrend történelmi gyökereit (1), majd ezt követően megvizsgálja meghatározásának és alkalmazhatóságának elméleti kérdéseit (2). Kísérletet tesz a különleges jogrend igazolására, illetve számba veszi az abban védett értékeket (3), majd végül összegzést nyújt (4).

\section{Történeti gyökerek és eszmetörténeti fejlődés}

A valamely külső vagy belső ok miatt felborult állami múködés és döntéshozatali rend helyébe lépő kivételes hatalomgyakorlás ideiglenes lehetősége nem új keletû jelenség az államelmélet történetében. A hatalom természetét és a hatalomgyakorlás funkcióit már az ókori görögök az athéni demokráciákban is vizsgálták. ${ }^{4} \mathrm{Az}$ arisztotelészi államformatan

2 Horkay Hörcher Ferenc a Politikafilozófia járványidején címú írásában mutat rá arra, hogy a politikai hatalomnak Szkülla és Kharübdisz, két véglet között kell hajóznia, és a legkisebb rosszat kell megtalálnia (Horkay Hörcher, 2020).

3 Az egyes európai országok koronavírus-járvány miatt bevezetett különleges jogrend összehasonlító vizsgálatáról lásd például: Ungvári-Hojnyák, 2020.

4 Trócsányi, 2014, 33. 0. 
vizsgálta a hatalomgyakorlás döntési aspektusait, és arra a következtetésre jutott, hogy a veszélyek elhárítása hatékonyabb, ha egyetlen vagy csak néhány személy kezében összpontosul a hatalom, ugyanis így a demokratikus hatalomgyakorláshoz képest egyszerúbb a jogkorlátozó döntések meghozatala.

Az athéni demokrácia mellett az ókori Róma államszervezetében az állandó magisztrátus mellett ismert volt a főhatalmat koncentráló rendkívüli magisztrátus (magistratus extraordinarii) intézménye. A rendkívüli magisztrátus a tisztségét kinevezéssel nyerte el megszabott időtartamra és meghatározott feladat elvégzése céljából. Ilyen rendkívüli magisztrátus volt a szükséghelyzetekben az egyik consul által a szenátus egyetértésével kinevezett - korábban consuli tisztséget viselt - dictator, aki legfeljebb hat hónapig gyakorolhatta a főhatalom teljességét. ${ }^{5}$

Az ókori görög és római előzményeket követően az államtörténelem azon szakaszaiban, amikor az állami múködés jog általi korlátozottsága csak viszonylagos volt, illetve amikor az abszolút szuverenitás teóriájára épült, nem merült fel a kivételes hatalomgyakorlás vagy a különleges jogrend megteremtésének az igénye. Ezekben a korszakokban ugyanis a fóhatalom gyakorlása nem volt olyan korlátozott, hogy kivételes helyzetek rögzítését igényelte volna. A kivételes hatalom és a különleges jogrend szabályozása a hatalommegosztás, a törvényeknek alávetett állami múködés elvével, az alapjogok elismerésével és a jogforrási hierarchia érvényesítésével nyert ismét értelmet. ${ }^{6}$ Ennek megfelelően a kivételes hatalomgyakorlás kérdései az újkori polgári államisághoz kapcsolódó alkotmányelméletekben jelentek meg. John Locke felfogása szerint a különleges helyzetekben a szuverenitásból fakadó főhatalom a közösség javára és a közjó megóvása érdekében akár a jog ellenében is gyakorolható. Ebben az értelmezésben tehát a kivételes hatalomgyakorlás összeforr a közjó érvényesítésével.7 Ezzel összhangban a polgári átalakulást követő modern kori államteóriák két nagyobb csoportba sorolhatók. Az első csoportba tartozók azt vallják, hogy a kivételes hatalomgyakorlás jogon kívüli jelenség, míg a második csoporthoz tartozók szerint a jog (alkotmány) uralma a kivételes hatalomgyakorlás során is érvényesül.

Carl Schmitt, az első csoporthoz tartozók híres képviselője azt vallja, hogy a kivételes hatalomgyakorlást igénylő különleges helyzetek nem láthatók előre, következésképpen pedig a jog nem is képes ezeket meghatározni. ${ }^{8}$ Hasonlóan vélekedik Friedrich Koja is, aki szerint a különleges állapot az, amely nem vagy nem hatékonyan kezelhető a jog eszközeivel. ${ }^{9}$ Schmitt olvasatában az alkotmányok funkciója legfeljebb az lehet, hogy meghatározzák azt, aki a kivételes hatalmat a különleges helyzetekben gyakorolhatja. Ez pedig nem (lehet) más, mint a szuverén,

5 Földi-Hamza, 1996, 19-23. o.

6 Farkas, 2020a, 324-325. o.

7 Locke, 1999.

8 Carl Schmitt úgy fogalmaz, hogy „a kivételes állapot nem határozható meg az érvényes jogrend keretein belül, nem írható körül tényállásként, legfeljebb a végszükség állapotaként, az állam létének veszélyhelyzeteként stb. jellemezhető" (Schmitt, 1992, 1-2. o.).

9 Koja, 2003, 797. 0. 
aki egyfelől a különleges helyzet megállapításáról dönthet, másfelől pedig a kivételes hatalmat is gyakorolhatja a veszélyeztető vagy fenyegető helyzet elhárítása, valamint a „normális” állapot helyreállítása érdekében. Ezt a két különböző döntést a szuverenitás gyakorlója jogosult meghozni, a hatáskörének feltételeit és tartalmát a jog nem köti. Schmitt értelmezése szerint tehát a szuverenitás letéteményese a jog által nem kötött és nem is származtatott jellegú politikai eredetú hatalom. ${ }^{10}$ Ezt a tételt azzal igazolja, hogy a szuverénnek áll hatalmában felfüggeszteni a pozitív jogot, vagyis a kivételes hatalomgyakorlás elszakad a jogtól. ${ }^{11}$

Ezzel ellentétes álláspontot fogalmaz meg például az angolszász jogfelfogást képviselő Albert V. Dicey, aki szerint a kivételes hatalomgyakorlás része a jognak, és ennek megfelelóen utólagos bírói megítélés tárgyát képezi. ${ }^{12}$ Ennek megfelelően a főhatalom kizárólag a jog uralmával összhangban gyakorolható. ${ }^{13}$ Ehhez hasonló álláspontra helyezkedik Schmitt kortárs kritikusa, Hans Kelsen is, aki tagadja a jogon kívül álló szuverén létezését. Álláspontja értelmében az állam és a jog nem válik el egymástól, mert az állami jogrendben a hierarchikusan felépülő jogi normák szükségszerûen egymástól, végső soron pedig az alapnormától nyerhetik el érvényességüket. Következésképpen, az olvasata szerint, ez a hierarchikusan felépülő jogrendet megkerülő hatalomgyakorlás érvénytelen..$^{14}$

Az első világháború időszakában Robert Hoerni a szükséghelyzet jogát (droit de nécessité) a lausanne-i föderális bíróság 1915. december 14-i döntésére alapozta, amely szerint a kormány a kivételes, rendkívüli körülmények (circonstances exceptionnelles) következtében nincs kötve az alkotmányhoz. A rendkívüli körülmények előre nem határozhatók meg, így az alkotmányi szabályozás sem lehetséges. Az állam jogos önvédelme a természetjogon alapszik. ${ }^{15}$ Ezzel szemben foglalt állást Duguit, aki úgy vélte, hogy a szükséghelyzetre alapított hatalomgyakorlás illegális. ${ }^{16}$ Mindazonáltal az alábbi feltételekkel el tudta fogadni a törvényhozás helyetti rendeleti jogalkotást:

- háború, fegyveres konfliktus, a köztisztviselók általános sztrájkja;

— a parlament nem tud összeülni, illetve összehívása jelentős késedelemmel járna;

- a rendeleti jogalkotást a parlament utólagosan jóváhagyja, amint arra lehetősége van. ${ }^{17}$

Németországban Jellinek a kormány kivételes hatalomgyakorlását szintén azzal a feltétellel tudta elfogadni, amennyiben a parlament utólagosan legitimálja a rendkívüli helyzetben elfogadott intézkedését. Carré de Melberg szerint az alkotmány tól való eltérés illegális,

10 Schmitt, 1992.

$11 \mathrm{Az}$ állam ezekben a helyzetekben lényegében elhagyja az általános rendet, és egy sajátos új rendet tételez, egyfajta alternatív jogrendet hoz létre. Erről lásd bővebben: Kelemen, 2020a, 189-190. 0.

12 Dicey, 1902.

13 Mészáros, 2017, 36-38. o.

14 Kelsen, 2001.

15 Hoerni, 1917.

16 Duguit, 1923.

17 Saint-Bonnet, 2001. 
abban az esetben, amennyiben ez a rendkívüli helyzetre tekintettel megtörténne, az az alkotmány tacitus módosításával lenne egyenértékúu. ${ }^{18}$

Az államelméleti vitákon túl a gyakorlatban a polgári átalakulás eredményeként megalkotott alkotmányokban kellett választ nyújtani a védelmi és biztonsági kihívásokat jelentő különleges helyzetek kezelésére. Ez elsősorban azért jelentett kihívást a korábbi korszakokhoz képest, mert a jogforrási hierarchia érvényesülése, a hatalmi ágak elválasztása és az egymást ellenőrző garanciális funkciója folytán az államszerkezet összetettebbé, az állami müködés és döntéshozatal pedig nehézkesebbé és időigényesebbé vált. A kivételes hatalomgyakorlásra, valamint a rendes múködéstôl eltérő állammúködésre a közjó és a közérdek védelme érdekében lehetőséget biztosító különleges jogrend gyakorlati megvalósulása és alkotmányjogi fogalma ezért a kartális alkotmányok 19. századi elfogadásához kapcsolódik. A hatalmi ágak elkülönítésével, a végrehajtó hatalom joghoz kötésével és ellenőrzésével a kivételes hatalomgyakorlás az alkotmányos rend szerves részévé vált. Ekkor gyökeresedtek meg a hatalomgyakorlás angolszász és kontinentális (német és osztrák) modelljei, amelyek között kell számon tartani a Magyar Királyság területén is érvényesülő kivételes hatalomról szóló 1869-es törvényt. ${ }^{19}$ Hosszú előkészítő munkát követően ezek az előzmények ágyaztak meg az első hazai kivételes hatalmi törvény 1912-es elfogadása előtt is. Az „állami létérdeket” szem előtt tartó szabályozást a garanciális jellege és körültekintő igényessége miatt olyan neves jogtudósok méltatták, mint Angyal Pál, Edvi Illés Károly és Búza László jogászprofesszorok. ${ }^{20}$

A 20. század második felétől kezdődően az alkotmányos rendszerekben a különleges jogrend kihirdetésére az alkotmányban meghatározott feltételek fennállása esetén - az embereket, az államot és az alkotmányos rendet veszélyeztető körülmény elhárítása érdekében nyílik lehetôség akkor, ha az állami múkködés hagyományos rendje és rendes jog eszközei nem bizonyulnak elégségesnek a veszély elhárításához. ${ }^{21}$ Kitapintható, hogy ez az „alkotmányközpontú" felfogás a különleges jogrendre az alkotmányosság részeként tekint, szemben az úgynevezett „államközpontú” felfogással, amely a szuverenitást előtérbe helyezve vallja, hogy a pozitív jog nem korlátozhatja az állami múködés rendkívüli helyzetben való cselekvését. ${ }^{22}$ $\mathrm{Az}$ „alkotmányközpontú” felfogás elfogadásával és térnyerésével a különleges jogrend keretei között megvalósuló kivételes hatalomgyakorlás - hasonlóan az alapjogokhoz vagy a bírói fe-

18 Saint-Bonnet, 2001.

19 Erről részletesen lásd: Kelemen, 2020b, 43-76. o.

20 Részletesen lásd: Kelemen, 2020c, 96-106. o.

21 Többek között Csink Lóránt jut arra a következtetésre, hogy a különleges jogrend bevezetését és az abban meghatározott állami múködést nem a jelenség, vagyis a különleges helyzet, hanem a veszély indokolja (Csink, 2017, 8-9.). Hasonlóan lásd: Chowdhury, 1989.

22 Jakab András és Till Szabolcs különbséget tesz az „alkotmányközpontú” és „államközpontú” felfogás között a hatalomgyakorlás joghoz kötöttsége szempontjából (Trócsányi-Schanda, 2014, 470-471. o.). 
lülvizsgálat intézményéhez - egyfajta alkotmányjogi garanciaként is szolgál a kormányzás során. ${ }^{23}$ Egyszerre jelent szélesebb kormányzási felhatalmazást és alkotmányjogi garanciát. ${ }^{24}$

A nemzeti alkotmányok nem mindegyike ismeri a kivételes hatalomgyakorlást, mindazonáltal az alkotmányos szokásjog alapján számos országban a jogrend részének tekintik. ${ }^{25}$

\section{A különleges jogrend meghatározása és alkalmazhatósága}

A kivételes hatalomgyakorlás és a különleges jogrend bevezetése mindig feltételez valamilyen különleges helyzetet. A különleges helyzet lehet valamilyen erőszakos jelenség, mint például külső és belső fegyveres konfliktus vagy akár kibertámadás; természeti csapás és ipari szerencsétlenség, mint például egy árvíz vagy járvány; valamint gazdasági és társadalmi válság is. A különleges helyzetek sajátossága, hogy bár tipizálhatók, de kimerítő módon semmiképpen sem határozhatók meg, ugyanis az idők során folyamatosan bővülnek újabb és újabb jelenségekkel, míg eközben a korábban súlyos veszéllyel járó jelenségek a tudomány és technológia fejlődésének köszönhetően már nem vagy jóval kevésbé jelentenek fenyegetést. ${ }^{26} \mathrm{~A}$ különleges helyzetek közös jellemzője ugyanakkor, hogy azonnali és gyors állami beavatkozást - válságkezelést - igényelnek. A különleges jogrenddel összefüggő egyik legjelentősebb kérdés ugyanakkor az, hogy milyen különleges helyzet indokolhatja a különleges jogrend bevezetését, illetve ki jogosult erról dönteni.

A különleges helyzet és a különleges jogrend kapcsolatát, illetve a különleges jogrend természetét övezően a hazai jogirodalom számos különböző elméleti felfogást ismer. Az egyik népszerú felfogás kiindulópontját a szabadság és a biztonság dichotómiája jelenti, amely szerint a különleges jogrend a társadalom múködésének az az állapota, amelynél fogva a biztonság súlyos mértékben fenyegetett. Az állam a különleges jogrend keretei között megalkotott speciális szabályok segítségével garantálja a biztonságot, jelentősebb mértékú alapjog-korlátozás az ára, vagyis többet kell áldozni a szabadságból. ${ }^{27} \mathrm{Ez}$ a fenyegetettség jelenik meg abban a meghatározásban, amelynek értelmében kivételes hatalom akkor gyakorolható, ha az „ország rendkívüli helyzetben van külső vagy belső fenyegetettség okán”. ${ }^{28}$ Más felfogások szerint a különleges jogrend bevezetésére az úgynevezett „alkotmányveszélyeztető helyzetek" adnak okot, míg a különleges jogrend olyan szabályok megalkotását teszi lehetôvé,

23 E körben érdemes felidézni Friedrich Koja szavait, aki szerint „a szülkségállapot egy alkotmányos állapot és nem az alkotmánynélküliség állapota" (Koja, 2003, 799. o.).

24 Ezzel összhangban mutat rá Varga Zs. András arra, hogy jelenleg az állami hatalomgyakorlással szemben alkotmányjogi és nemzetközi jogi elvárás, hogy a jogban legyen szabályozott, a hatalomgyakorlás joghoz kötöttsége „mára előíróvá (normatívvá, perspektívvé) vált” (Varga Zs., 2015, 11-12. o.).

25 Svájcban például sikertelen törekvések voltak a kivételes jogrend alkotmányi szintû szabályozására, mindezek ellenére a kivételes hatalomgyakorlást meghatározott esetekben a jogrend részének tekintik (Kley, 2020).

26 Részletesebben lásd: Csink, 2017.

27 Csink, 2017, 8-9. o.

28 Bódi, 2016, 45. o. 
„amelyek egyrészt a cselekvés alkotmányos kötelezettségeit lazítják (hatékonyság), másrészt viszont védelmet is biztosítanak az e lazításokkal való esetleges visszaélésekkel szemben". ${ }^{29}$ Ezt a kiindulópontot veszi alapul az az álláspont, amely szerint a különleges jogrend „alapvetően az állam rendkívüli helyzetekben való múködőképességének, az állami szuverenitás, az alkotmányos rend, az állampolgárok élet- és vagyonbiztonságának fenntartását biztosító jogi szabályozási keret létrehozása volt". ${ }^{30}$ Ehhez képest a funkcionális megközelítés talaján álló álláspontok érdeklődésének terében az rejlik, hogy a különleges jogrend mennyiben támogatja az állam múködését és védelmi erőfeszítéseit. ${ }^{31}$ Ennek megfelelően a különleges jogrendet a válságkezelés eszközének tekinti, „a válságkezelés dinamikus folyamatának egy közjogi döntésekkel meghatározott szakaszát jelenti, amikor a válság normál jogrend keretei között eredményesen már nem kezelhetô". ${ }^{32}$

Ezeket a jogirodalmi álláspontokat alapul véve a különleges jogrend leginkább egyfajta „immunreakcióként" jellemezhetô, amelyben a rendhagyó állami mưködés nyújt orvoslást olyan válságra vagy veszélyre, amelyet a nehézkesebb és időigényesebb hagyományos állami múködés keretei között már nem lehet kezelni. Ennek figyelembevételével a különleges jogrend jellegadó sajátosságai közé tartozik egyfelől az időbeli korlátozottság,,33 másfelől pedig, a védelmi jellegéből fakadóan az, hogy a hagyományos állami múködés mielőbbi visszaállítására törekszik. Ennek megfelelően a különleges jogrend nemcsak rendhagyó állami múködést jelöl, hanem az állam (ön)védelmi eszköztárának utolsó eleme. ${ }^{34}$ A neves jogtudós, Concha Győző a rendkívüli állapotot és a kivételes hatalomgyakorlást természetszerú igénynek, az államiság szükségszerü részének tartotta, szavai szerint a kivételes állapot az állam vagy a társadalom megvédéséhez és a közrend fenntartásához szükséges eszköz. ${ }^{35}$ Olvasatában a kivételes hatalomgyakorlásra a folyamatosan megjelenő fenyegetések elhárítása érdekében a világ valamennyi táján nélkülözhetetlen szükség mutatkozik. Az egyes nemzeti szabályozások csupán abban különböznek, hogy ki jogosult a kivételes hatalomgyakorlás és a különleges jogrend kihirdetésére, és milyen terjedelmú felhatalmazás birtokában járhat el a kivételes hatalmat gyakorló. ${ }^{36}$

Ezek figyelembevétele alapján a különleges jogrend alkalmazásának előfeltételeként és egyben garanciális korlátjaként vehető számba, hogy a leküzdendő veszély vagy válság

29 Jakab-Till, 2014, 466. o.

30 Lakatos, 2014.

31 Kádár Pál véleménye szerint a különleges jogrend lényege, hogy a „normál békeidőszaki múködéshez képest egyes állami szervek vagy személyek kiegészítő jogosítványokat kapnak, míg más személyek vagy szervek jogai korlátozásra kerülnek a válsághelyzet megoldása érdekében” (Kádár, 2014, 6. o.).

32 Keszely, 2017.

33 Ezzel áll összhangban Tomcsányi Móric találó megfogalmazása, amely szerint: „A kivételes hatalom mindig átmeneti jellegú s ennyiben is kivételes. A törvényhozás a rendkívüli viszonyok hatása alatt csak ideiglenesen e szükséghelyzet tartamára és persze a megjelölt alkotmányi határok között engedi át saját rendelkező hatalmának gyakorlását a kormánynak, s a rendkívüli viszonyok megszúntével e kivételes rendeletek érvénye is megszúnik. Ez az átmeneti jelleg is egyik ismertető vonása a kivételes hatalomnak [...]." Idézi: Farkas, 2020a, 329-330. o.

34 Farkas, 2020b, 26-28. o.

35 Concha, 1905, 386. o.

36 Farkas, 2020a, 329-330. o. 
a közösség valamilyen - alkotmányban is kifejezésre jutó - értékét fenyegeti. Ezen túl a fenyegetettség elhárításához állami beavatkozás szükséges, ugyanakkor az állami múködés hagyományos rendje ehhez nem elégséges, vagyis ultima ratióként szolgál a veszély vagy a válság leküzdéséhez. ${ }^{37}$ Végül pedig a különleges jogrend alkalmazásának korlátozottságát kiegészítő további ismérv - mint ahogyan azt a hatalomgyakorlás kivételessége is tükrözi az intézmény átmenetisége, vagyis időleges jellege.

\section{A különleges jogrend igazolhatósága és az abban védett értékek}

Mint ahogyan az előző rész kitért rá, a jogállamokban a különleges jogrend egyik kulcsfontosságú alkotmányjogi kérdése, hogy mely különleges helyzetek igazolhatnak kivételes hatalomgyakorlást. Ebből a szempontból figyelemre méltó a különleges jogrend kétarcúsága. Egyfelől a politikai döntéshozatal és a jogalkotási folyamat koncentrálásán, illetve a jogforrási hierarchia szigorú érvényesítésének részleges feloldásán keresztül az állami múködés hatékonyságát és időszerüségét erősíti, másfelől pedig szélesebb teret nyit bizonyos alapvető jogok korlátozása előtt.

E körben ugyanakkor szükséges hangsúlyozni, hogy míg az előbbi a különleges jogrend bevezetésének oka, addig az utóbbi legfeljebb csak elkerülhetetlen velejárója lehet. Másként fogalmazva: a kivételes hatalomgyakorlás olyan - kimerítő jelleggel előre nem meghatározható vagy felsorolható - válsághelyzetek elhárítását vagy kezelését szolgálja, amelyek az összetett, nehézkes, vitákkal terhes és időigényes hagyományos állami múködés rendjében már egyáltalán nem vagy nem kellően orvosolhatók, ${ }^{38}$ és annál hatékonyabb védelmi intézkedéseket, azonnali döntéshozatalt, illetve gyorsabb állami beavatkozást igényelnek. ${ }^{39}$ Ez a gyors állami múködés pedig feltételezi a hatalommegosztás és a jogforrási hierarchia hatalomkorlátozásának lazítását. Ennek megfelelően találó az a hasonlat, amely a különleges jogrendet - utalva annak ultima ratio jellegére - a jogállam vagy az alkotmányosság jogos védelmi helyzeteként aposztrofálja. ${ }^{40} \mathrm{~A}$ kivételes hatalomgyakorlásra és a különleges jogrend bevezetésére ugyanis az államiság, az alkotmányos rend vagy a társadalom fennmaradását veszélyeztető, súlyos fenyegetés teremthet lehetőséget. Ennek során a hagyományos állami múködés a fenyegetés mértékéhez igazodóan és annak eredményes elhárításáig felfüggeszthető. Emellett azonban a kivételes hatalomgyakorlás - a jogos védelem intézményéhez hasonlóan - nem jelenthet egy jogon (vagy alkotmányon) kívüli állapotot, hanem maga is

37 Farkas, 2020a, 323, 339. o. Hasonló elvet fogad el az Emberi Jogok Európai Bíróságának gyakorlata is, erről lásd: Mészáros, 2016, 208. o.

38 Ennek megfelelően Magyary Zoltán álláspontja szerint a parlamentáris rendszer csak a békés viszonyok között alkalmas kormányzásra, míg fenyegető helyzet idején hatékonyabb döntéshozatalra kell törekedni (Magyary, 1942, 206. o.).

39 A válság és a különleges jogrendi időszak kapcsolatáról részletesen lásd: Keszely, 2017.

40 Erről lásd: Farkas, 2020a, 338. o. 
korlátos, ugyanis bizonyos alkotmányjogi garanciák, mint például a célhoz kötöttség vagy az alkotmánybírósági kontroll ezen idők során továbbra is érvényesek maradnak.

Erre figyelemmel bizonyos alapvetô jogok korlátozása a különleges jogrendnek önmagában nem lehet célja, hanem a fenyegetés elhárításának csak szükséges eszköze és ezáltal velejárója. A különleges jogrend konstituálásának kiváltó oka ugyanis nem az alapvető jogok korlátozása, hanem olyan különleges helyzet, amely gyors és hatékony állami beavatkozást igényel. Sót, a jogos védelmi helyzet analógiája alapján, amennyiben a különleges jogrend bevezetésére okot adó fenyegetés az alkotmányt vagy az abban kifejezésre jutó értéket veszélyezteti, úgy a kivételes hatalomgyakorlás közvetlen és közvetett jogot védő funkcióval rendelkezik. A különleges jogrend közvetlen jogot védő funkciója abban nyilvánul meg, hogy a közösség számára becsesebb vagy korlátozást nem engedő jogok javára és erősebb védelme érdekében más jogok korlátozásának tiszteletben tartását követeli meg; bizonyos, alkotmányban elismert jogok védelmét előrébb sorolja. Így például a járvány idején - a vírus gyors terjedésének lassításán vagy megakadályozásán keresztül - az emberi élet és egészség fokozottabb védelme érdekében rendeli el a gyülekezés jogának, a vallás vagy a mozgás szabadságának korlátozásait. Ugyanakkor a kivételes hatalomgyakorlás és a különleges jogrend emellett közvetett módon is rendelkezik jogot védő funkcióval, amennyiben a kivételes közhatalmi intézkedéseknek a fenyegetés elhárítására és a hagyományos alkotmányos rend - beleértve az abban elismert alapvetô jogok és szabadságok teljes érvényesülése - mihamarabbi visszaállítására kell irányulniuk. Másként fogalmazva, a különleges jogrend átmenetisége az alkotmányos jogok teljes spektrumának érvényesülését szolgálja.

Látható tehát, hogy az alkotmány részeként szabályozott különleges jogrendnek az alkotmányos rendszerekben nélkülözhetetlen védelmi szerepköre van. Az államiságot, az alkotmányos rendet és a társadalmat veszélyeztető fenyegetések elhárításával ugyanis végső soron az alkotmányban kifejezett értékek megóvására irányul. Ez a szükségszerú értékvédő funkciója jelenti a kivételes hatalomgyakorlás és a különleges jogrend legfontosabb jelenkori igazolását.

\section{Végső következtetések}

A tanulmány felvázolta a kivételes hatalomgyakorlás és a különleges jogrend történelmi gyökereit, eszmetörténeti alapvonalait, valamint újkori megjelenését, funkcióját és igazolhatóságát. Ez utóbbi körben érdemes felidézni Deák Ferencet, aki egykoron úgy fogalmazott, hogy „az ostromállapot szomorú kényszerúség; Isten mentse a hazát, hogy rá szükség legyen; de az ostromállapotnál még súlyosabb állapot az, ha nincs törvény, mely azt szabályozza, és ha az ostromállapoti törvény helyett önkény lép a sorompóba". ${ }^{41}$ E veretes szavakkal összhangban a tanulmány egyik fontos elméleti következtetése, hogy a régmúltra visszatekintő és a jelenkori

41 Idézet Deák Ferencnek a katonai bíróságok hatásköréről szóló 1868. évi vitában december 6-án elhangzott felszólalásából. Lásd: Greguss, 1868, 380. o. Idézi: Farkas, 2020a, 328-329. o. 
alkotmányos kultúrákban egyetemesen érvényesülő különleges jogrend olyan alkotmányjogi vívmány, amely garanciális jelentőségú a nemzeti alkotmányos értékek megóvásához.

\section{Irodalomjegyzék}

BóDI, S. (2016) 'A civilizációk összecsapása? A tömeges bevándorlás által életre hívott migrációs válsághelyzet elemzése és a különleges jogrend', Hadtudomány, 26(1-2), 41-51. o.

CHOwdhurY, S. R. (1989) Rule of Law in a State of Emergency: The Paris Minimum Standards of Human Rights Norms in a State of Emergency. 1. kiadás. London: Pinter Publishers

ConchA, Gy. (1905) Politika II. Közigazgatástan. 1. kiadás. Budapest: Grill Károly Könyvkiadóvállalata

Csınk, L. (2017) 'Mikor legyen a jogrend különleges?', Iustum Aequum Salutare, 13(4), 7-16. o.

DiCEY, A. V. (1902) Bevezetés az angol alkotmányjogba. 1. kiadás. Budapest: Magyar Tudományos Akadémia

Duguit, L. (1923) Traité de droit constitutionnel. 1. kiadás. Paris: Tome

FARKAS, Á (2020b) 'Bevezetés a különleges jogrend témakörének fontosabb alapkérdéseibe' in Farkas, Á., Kelemen, R. (szerk.) Szkülla és Kharübdisz között - Tanulmányok a különleges jogrend elméleti és pragmatikus kérdéseiról, valamint nemzetközi megoldásairól. 1. kiadás. Budapest: Magyar Katonai Jogi és Hadijogi Társaság

FARKAS, Á. (2020a) 'Gondolatok a különleges jogrend természetéről a modern államiságban' in Farkas, Á., Kelemen, R. (szerk.) Szkülla és Kharübdisz között - Tanulmányok a különleges jogrend elméleti és pragmatikus kérdéseiről, valamint nemzetközi megoldásairól. 1. kiadás. Budapest: Magyar Katonai Jogi és Hadijogi Társaság

FöLDI, A., HAMzA, G. (1996) A Római Jog története és institúciói. 1. kiadás. Budapest: Nemzeti Tankönyvkiadó

GREGUSS, Á. (szerk.) (1868) Az 1865-dik évi deczember 10-dikére hirdetett Országgyülés képviselöházának naplója-tizenegyedik kötet. Pest: Athenaeum

HoERnI, R. (1917) De l'état de névessité en droit public fédérale suisse: étude juridique sur les pleins pouvoirs. 1. kiadás. Geneve: Société Générale d'Imprimerie

HORKAY HÖRCHER, F. (2020) Politikafilozófia járványidején [Online]. Elérhető: https://orszagut. com/nyomtatott_cikk/politikafilozofia-jarvany-idejen (Letöltve: 2020. december 15.)

JAKAB, A., TILL, Sz. (2014) 'A különleges jogrend' in Trócsányi, L., Schanda, B. (szerk.) Bevezetés az alkotmányjogba. Az Alaptörvény és Magyarország alkotmányos intézményei. 1. kiadás. Budapest: HVG-ORAC

KÁDÁR, P. (2014) 'A kivételes hatalomtól a különleges jogrend idején bevezethető intézkedésekig', Katonai Jogiés Hadijogi Szemle, 2(1), 5-46. o.

Kelemen, R. (2020a) 'A különleges jogrend, mint jogrendi fogalom jellemzői' in Farkas, Á., Kelemen, R. (szerk.) Szkülla és Kharübdisz között-Tanulmányok a különleges jogrend elméleti 
és pragmatikus kérdéseiról, valamint nemzetközi megoldásairól. 1. kiadás. Budapest: Magyar Katonai Jogi és Hadijogi Társaság

KELEMEN, R. (2020b) 'A különleges jogrend történeti modelljeinek kialakulása és fejlődése a 20. század második évtizedének végéig' in Farkas, Á., Kelemen, R. (szerk.) Szkülla és Kharübdisz között - Tanulmányok a különleges jogrend elméleti és pragmatikus kérdéseirōl, valamint nemzetközi megoldásairól. 1. kiadás. Budapest: Magyar Katonai Jogi és Hadijogi Társaság

KELEMEN, R. (2020c) 'Az 1912-es kivételes hatalmi törvény születése és rendszere' in Farkas, Á., Kelemen, R. (szerk.) Szkülla és Kharübdisz között - Tanulmányok a különleges jogrend elméleti és pragmatikus kérdéseirōl, valamint nemzetközi megoldásairól. 1. kiadás. Budapest: Magyar Katonai Jogi és Hadijogi Társaság

Kelsen, H. (2001) Tiszta jogtan. 1. kiadás. Budapest: Rejtjel

KeszelY, L. (2017) 'A különleges jogrend a védelmi igazgatás gyakorlati jogalkalmazói szemszögből', Iustum Aequum Salutare, 13(4), 77-89. o.

KLEY, A. (2020) Pleins pouvoirs [Online]. Elérhetô: https://hls-dhs-dss.ch/fr/articles/010094/ 2020-10-06/ (Letöltve: 2020. december 15.)

KojA, F. (2003) 'Állami szükségállapot és a szükségállapotra vonatkozó jog' in Takács, P. (szerk.): Államtan - Írások a XX. századi általános államtudomány köréből. 1. kiadás. Budapest: Szent István Társulat

LAKaTos, L. (2014) 'A különleges jogrend és a honvédelem szabályzása', MTA Law Working Papers, 2014/49. [Online]. Elérhető: https://jog.tk.hu/mtalwp/a-kulonleges-jogrend-es-ahonvedelem-szabalyzasa (Letöltve: 2020. december 8.)

LOCKE, J. (1999) Másodikértekezés a polgári kormányzatról. 1. kiadás. Budapest: Polis

Magyary, Z. (1942) Magyar közigazgatás. 1. kiadás. Budapest: Királyi Magyar Egyetemi Nyomda

MÉszÁros, G. (2016) 'Alapjogi bíráskodás különleges helyzetekben: a strasbourgi bíróság releváns esetjoga', Pro Futuro, 6(2), 200-218. o.

MÉszÁros, G. (2017) 'Uralhatja-e a jog a kivételes állapotot? A kivételes állapot elmélete a két rivális álláspont alapján', Iustum Aequum Salutare, 13(4), 31-41. o.

SAINT-Bonnet, F. (2001) L'état d'exception. 1. kiadás. Paris: Presses Universitaires de France SCHмIтT, C. (1992) A politikai teológia. 1. kiadás. Budapest: ELTE ÁJK

TrócsánYi, L. (2014) 'Alaptanok' in Trócsányi, L., Schanda, B. (szerk.) Bevezetés az alkotmányjogba. Az Alaptörvény és Magyarország alkotmányos intézményei. 1. kiadás. Budapest: HVG-ORAC

UngVÁRI, Á., HoJnYÁk, D. (2020) 'Az Európai Unió egyes tagállamainak koronavírusjárványra adott válasza, különös tekintettel a vizsgált államok által bevezetett különleges jogrendi szabályozásra', Miskolci Jogi Szemle, 15(1), 122-138. o.

VARGA Zs., A. (2015) Eszménybőllbálvány? Ajoguralom dogmatikája. 1. kiadás. Budapest: Századvég 